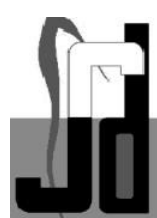

\title{
REVIEW
}

\section{Cytokines in Periodontal Health \& Disease}

\author{
Sreedevi M, Vineela Katam Reddy, Anitha K
}

ABSTRACT: Destruction of gingival and periodontal tissue is mediated by a very large degree of host cells following stimulation by locally produced cytokines. These cytokines act as the initial mediators of the cellular component of inflammation. It has now been shown that a range of bacterial molecules is able to induce human cells to produce a variety Of pro and anti-inflammatory cytokines. It is clear that cytokines play a key role in the immune system, in hematopoiesis, and in immunoregulation. They also play a role in the pathophysiology, both in producing tissue destruction as well as in healing. Host cells such as keratinocytess fibroblasts, endothelial cells and tissue monocytes respond to certain bacterial proteins and lipopolysaccharides by generating primary proinflammatory cytokines. Their excessive production in chronic inflammation may have pathologic consequences in diseases su ch as periodontitis.

Cytoki nes are a significant and integral part of the host response to periodontal infection. Additionally, these molecules are important as physiologic mediators in the periodontium, serving in both normal processes and as pathogenic mediators. A therapeutic goal in clinical periodontics can be aimed at maintaining a physiological role for the cytokines while recognizing that their overproduction results in pathologic changes.

Key words: Cytokines, periodontal disease, interleukins, chemokines, growthfactors, cytokine therapy.

\begin{abstract}
Multi cellular organisms use a wide variety of chemical signals to control and coordinate cellular activities for normal life sustaining operations as well as for mounting defenses against foreign organisms. The complex interaction among lymphocytes, inflammatory cells and other cellular elements in the connective tissues are mediated by a series oflow molecular- wei ght proteins called "CYTOKINES". ${ }^{[1]}$ Cytokines are signaling molecules that are also involved in the regulation of growth and development, activation of immune system cells and in the medi ation of inflammatory responses.
\end{abstract}

Periodontal diseases are infectious diseases. The pathology of periodontitis lesions is characteristic of, and consistent with, a subversion of host defenses against bacterial pathogens erially-induced hostmedia periodontal tissues.

iodontal tissue is mediate host cells following stimul okines. Some signaling and activate the body's defense system
15 Journal of Scientific Dentistry, 1(1), 2011

against offending microorganism, molecules of bacterial origin act as the signaling molecules. Host cells such as keratinocytes, fibroblasts, endothelial cells and tissue monocytes respond to certain bacterial proteins and lipopolysaccharides by generating primary proinflammatory cytokines. These cytokines act as the initial mediators of the cellular component of inflammation. Primary proinfl ammatory cytokines activate resident cells such as fibroblasts and endothelial cells to generate secondary proinflammatory cytokines that have a chemoattractant effect on leukocytes. These chemoattractant cytokines amplify the inflammatory reaction and render specificity to the cellular response.

Included in the cytokine molecule group are interleukins, interferon, growth factors, cytotoxic factors, activating and inhibiting factors, colony stimulating factors, and intercrines. Cytokines are responsible for the maintenance of an intricate communication network between the homot pes. Thus, cytokines play an important numerous biological activities inc differentiation,

\begin{tabular}{|l|l|l|l|}
\hline \multicolumn{2}{|l|}{} & & \\
\hline & & \\
\hline & $\begin{array}{l}\text { Monocytes,macrophages } \\
\text { Eplthehum endothelium } \\
\text { fibroblasts }\end{array}$ & $\begin{array}{l}\text { Monocytes,macrophages, } \\
\text { T-cells,epithelium, } \\
\text { Hypothalamus endothelium }\end{array}$ & $\begin{array}{l}\text { Activation, t TNF-a \& IL- } \\
2, \text { fever }\end{array}$ \\
& & & \\
\hline
\end{tabular}




\begin{tabular}{|c|c|c|c|}
\hline & & $\mathrm{T} \& \mathrm{~B}$ cells & Activation \& $\mathrm{t}$ \\
\hline & $\mathrm{T}$ cells \& thymocytes & $\begin{array}{l}\text { Many leukocytes } \\
\text { differentiation }\end{array}$ & $\mathrm{t}$ proliferation \\
\hline & $\begin{array}{l}\text { Th2 cells mast } \\
\text { cells basophils }\end{array}$ & $\mathrm{T} \& \mathrm{~B}$ cells mast cells & $\begin{array}{l}\text { Promotes IgE production } \\
\& \mathrm{Th} 2 \text { cells, CMI }\end{array}$ \\
\hline & Th2 cells mast cells & $\begin{array}{l}\text { Eosinophils, B cells, } \\
\text { thymocytes }\end{array}$ & $\begin{array}{l}\text { Activates eosinophils, t } \mathrm{B} \\
\text { cell growth }\end{array}$ \\
\hline & $\begin{array}{l}\text { Th2cells,monocytes, } \\
\text { macrophages epithelium } \\
\text { endothelium }\end{array}$ & Ilepatocytes, B cells & $\begin{array}{l}\mathrm{t} \text { acute phase reactants } \mathrm{t} \\
\mathrm{IgM}, \operatorname{IgA} \text { production }\end{array}$ \\
\hline & $\begin{array}{l}\text { Monocytes,macrophages } \\
\text { epithelium }\end{array}$ & $\begin{array}{l}\text { Neutrophils, eosinophils, } \\
\text { monocytes, basophils,CDS+T }\end{array}$ & Activation, chemotaxis \\
\hline & $\begin{array}{l}\text { Th2cells,monocytes, } \\
\text { macrophages eprthellum }\end{array}$ & $\begin{array}{l}\text { Monocytes, macrophages } \\
\text { Th2 cells B cells }\end{array}$ & $\begin{array}{l}\text { production of IL- } 1, \mathrm{TNF}-\mathrm{u} \\
\& \mathrm{IL}-2, \mathrm{t} \text { IgA production }\end{array}$ \\
\hline & Monocytes, macrophages & NK cells, T cells & Activates NK \&Th1 cells \\
\hline Interferon & $\begin{array}{l}\text { Fibroblast } \\
\text { dendrrtrc cells }\end{array}$ & Many cells, NK cells & $\begin{array}{l}\text { Antiviral, } \mathrm{t} \text { MHC class } 1 \text {, } \\
\text { proliferation, } \mathrm{t} \text { cytolysis }\end{array}$ \\
\hline \multirow[t]{5}{*}{ Interferon } & $\begin{array}{l}\text { Thi cells, NK } \\
\text { cells, macrophages }\end{array}$ & Many cells, NK cells & $\begin{array}{l}\text { Antiviral,fever, proliferati } \\
\text { tMHC class } 1 \& 11 \& \mathrm{sc}\end{array}$ \\
\hline & $\begin{array}{l}\text { Macrophages, NK cells, } \\
\text { eplthellum mast cells }\end{array}$ & $\begin{array}{l}\text { Monocytes, macrophages, } \\
\text { hypothalamus }\end{array}$ & $\begin{array}{l}\text { Activates monocytes \& } \\
\text { PMNs, fever,anti-tumor }\end{array}$ \\
\hline & & Paracrme effects & \\
\hline & $\begin{array}{l}\text { Many cell types } \\
\text { Many cell types } \\
\text { Many cell types }\end{array}$ & $\begin{array}{l}\text { Neutrophil precursors } \\
\text { Monocyte precursors } \\
\text { Both }\end{array}$ & Growth \& maturation \\
\hline & $\begin{array}{l}\text { Tcells,monocytes, } \\
\text { macrophages }\end{array}$ & $\begin{array}{l}\text { Monocytes, B cells, T cells. } \\
\text { Macrophages epithelium }\end{array}$ & $\begin{array}{l}\text { t IgA \& IgE production, } \\
\text { inflammation }\end{array}$ \\
\hline
\end{tabular}

Cytokines in periodontal health and disease

homeostasis, regeneration, repair and inflamm

ation.

Research on the pathogenesis of the periodontal disease have clarified that cytokines play an imp ortant role.

Hence, this review reviews the cyokine expression in periodontal tissues and its importance in tissue homeostasis and in particular in the pathogenesis of periodontal diseases (Table-1).

\section{CYTOKINES IDENTIFIED IN SERA FROM PATIENTS WITH PERIODONTITIS}

It has recently been demonstrated that sera of patients with untreated, severe periodontitis, diagnosed on the basis of clinical and radiographical registrations, contained higher levels of IL-2, IL-2 receptors and IL4 than did sera of healthy individuals. ${ }^{151}$ Thus, IL-2 was detected in $10 \%$ of sera from the healthy controls, but in $88 \%$ of sera from periodontitis patients. Despite a wide variation in the xxIL-2 levels, there was no correlation between the degree ofbone loss or pocket formation and the amounts of IL-2 in serum. IL-4 in sera from individuals of the periodontitis group was also significantly increased as compared to sera from the control group. Future studies are needed to elucidate a possible use of IL-2 and/or IL-2 receptor and IL-4 levels in serum as markers ofperiodontitis activity.

\section{CYTOKINES IDENTIFIED IN PERIODONTAL TISSUES}

Different techniques have been used to demonstrate the presence of cytokines in gingival tissue. Thus immunohistochemical techniques have been used as well as ELISA and bioassays on supernatants from homogenized gingival tissue.

In a study of gingival tissue from periodontitis patients with red uced inflammation after $\mathrm{s}$ caling, the localization of IL- 113 was demonstrated by an immunohistochemical technique. [ ${ }^{61}$ IL- 1 B was located at or in individual lamina propria cells, which showed intense surface and cytoplasmatic 
staining.There was a three-fold increase staining intensity between

The presence of IL- $1 \beta$ has echnique in extracts from $\mathrm{h}$ nflamed gingival tissue of periodontitis patients- ${ }^{\mathrm{m}}$ The

17 Journal of Scientific Dentistry, 1(1), 2011

Sreedevi et al

cytokine was found in increased amounts supernatants from periodontitis lesions, and there was no

IL-1B in non-inflamed gingival tissue. Recent homogenized biopsies from patients with active or inactive disease as defined by the tolerance nethod, ${ }^{[8]}$ as well as from healthy gingival sites of adult periodontitis patients, showed an increased IL-1ß level in inflamed sites.

IL-lu, IL-1B, and TNFu were identified by ELISA in tissue from patients with chronic adult periodontitis. [101 The presence of the cytokines in frozen tis sue specimens was also shown by indirect immunofluorescence. The IL-1B and TNFu levels in diseased tissue were significantly higher than in healthy tissue. IL-lu was only revealed in a few diseased and healthy gingival sites. The IL-I F containing cells were present in much higher numbers than IL-I $u$ and TNFu containing cells.[10] The authors therefore suggested that important mediator in the pathogenesis ofperiodontitis.

Another study demonstrated both IL-lu and IL-I $\beta_{\mathrm{mRNA}}$ in all exami ned gingival biopsies from untreated patients with periodontitis. IL-IP mRNA dominated in almost all biopsies. TNFu-like activity has been found in supernatants of homogenized inflamed periodontal tissue using bioassay.

Recently, it was also suggested that IL-6 may participate in the patho genesis of periodontitis, since IL-6 was identified in inflamed human gingival tissue using an immunohistochemical technique. [1 3] The foci of inflammation showed intense staining for IL-6 in the MNC, and staining was also associated with resident fibroblasts. However, non-inflamed areas al so showed a positive staining reaction.

\section{CYTOKINES IDENTIFIED IN CREVICULAR FLUID}

The first studies of cytokines in crevicular fluid demonstrated the presence of a thymocyte-activating factor. [14,15] which was indistinguishable from IL-I with respect to biological activities and biochemical properties appeared that crevicular fluid inflamed sites contained more thymocyte-aeti om non-inflamed sites

Later, an IL-I -like factor in crevicular fluid from patients with chronic periodontitis was characterized. $\left[{ }^{171} \mathrm{~A}\right.$ study re vealed that the IL-I -like activity in crevicular fluid was completely neutralized by an antiserum to human recombinant IL-I $\mathrm{u}$, but not to IL-1ß. This result, however, is contrasted by another study which by using an ELISA-technique demonstrated IL-1ß more frequently than IL-la in erevieular fluid from untreated patients with periodontitis. [11 The discrepancy may be due to differences in assay techniques, and/or to differences between the groups of patients. The latter results are more compatible with the fact that IL-la is predominantly membrane-bound, whereas IL-1ß is readily secreted from the cells. $[18,19]$

TNFa has been detected in crevicular fluid but was not correlated with gingival index, plaque index, or probing depth- $\left[{ }^{20}\right.$ It was suggested that TNFa may be a marker of early inflammatory activity because of the pattern less distribution ofTNFu within the individuals and the lack of correlation of clinical inflammation with the TNFa levels.

IL-6 has been demonstrated by ELISA in crevicular fluid of five periodontitis patients. [211A significant correlation between bleeding index, probing depth, and the IL-6 levels of the crevicular fluids was also demonstrated.[21] Further research is needed to evaluate IL-6 as a possible marker ofperiodontal breakdown.

\section{CYTOKINE EXPRESSION IN PERIODONTAL HEALTH}

The type of immune response that occurs on exposure to a pathogen is vital in determining resistance or susceptibility to disease. The importance of the cytokines induced locally is paramount due to their different effects on the function of cells in the immediate neighborhood, which then determines the course of the response and hence the resistance or susceptibility to the particular pathogen. $\left[{ }^{22}\right]$ Once the 
epithelial barri ptides is breached and the e comes into play. Cytokines are central response, production "appropriate" cytokines tective immunity and the production of inappropriate cytokines leads to tissue destruction progression. [23] Just how the immune system chooses and regulates the right cytokines is unclear, although genetic factors are most likely involved.[24]

Tissue homeostasis represents a delicate balance between anabolic and catabolic activities. The regulations Of migration, proliferation and differentiation of resident cells and of the production of tissue matrix in a healthy state are major aspects of periodontal tissue homeostasis. $\left[{ }^{\beta}\right]$ There is abundant evidence that cytokines, which are secreted by fibroblasts, endothelial cells and epithelial cells, play a crucial role in tissue homeostasis. [25]

Cytokines interact in a network: first by inducing each other; second by transmodulating cell surface receptors; and third by synergistic, additive or antagonistic interactions on the cell function. [26]

The mRNA expression of cytokines in clinically healthy gingival tissues was examined by ureversetranscription/polymerase chain-reaction (RTPCR), mRNA expression of a variety of growth factors-such as Epidermal growth factor (EGF), Platelet-derived growth factor (PDGF), and Transforming growth fac tor- $\beta$ (TGFß)-was observed.[271

Interestingly, mRNA of so-called inflammatory cytokines (such as IL-I, IL-6, and TNF-u) was also detected in the clinically healthy gingival tissues, although their density was relatively low compared with that in the inflamed sites. This suggests that myriad cytokines may be involved in the maintenance of periodontal tissue tu rnover or integrity.

The biological activity of certain cytokines have been relatively well-chacterized through the research Of periodontal regeneration such as Insulin like growth factor (IGF), TGF- $\beta$ and cementum derived growth factorCGF)

\section{CYTOKINE GENE POLYMORPHISMS}

The inter-individual differences in the inflammatory response (and the differences in periodontal disease susceptibilit as well as the interaction bet kground may affect man inflammation periodontal 
Mechanism by which IL-I or TNF could contribute to the net loss ofperiodontal tissues

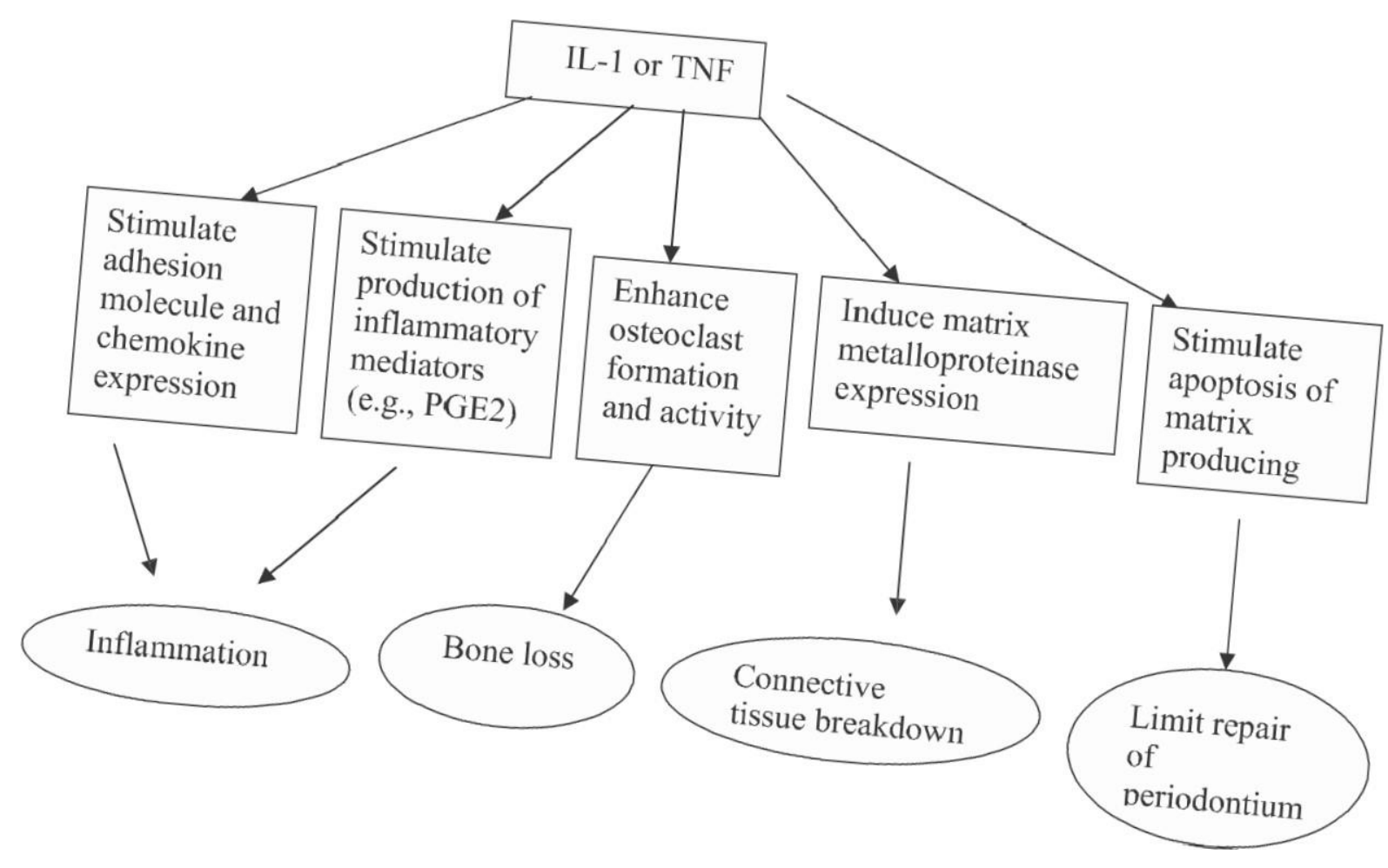

Table 2: Pathophysiological roles ofinnammatory cytokines in periodontal tissue destruction

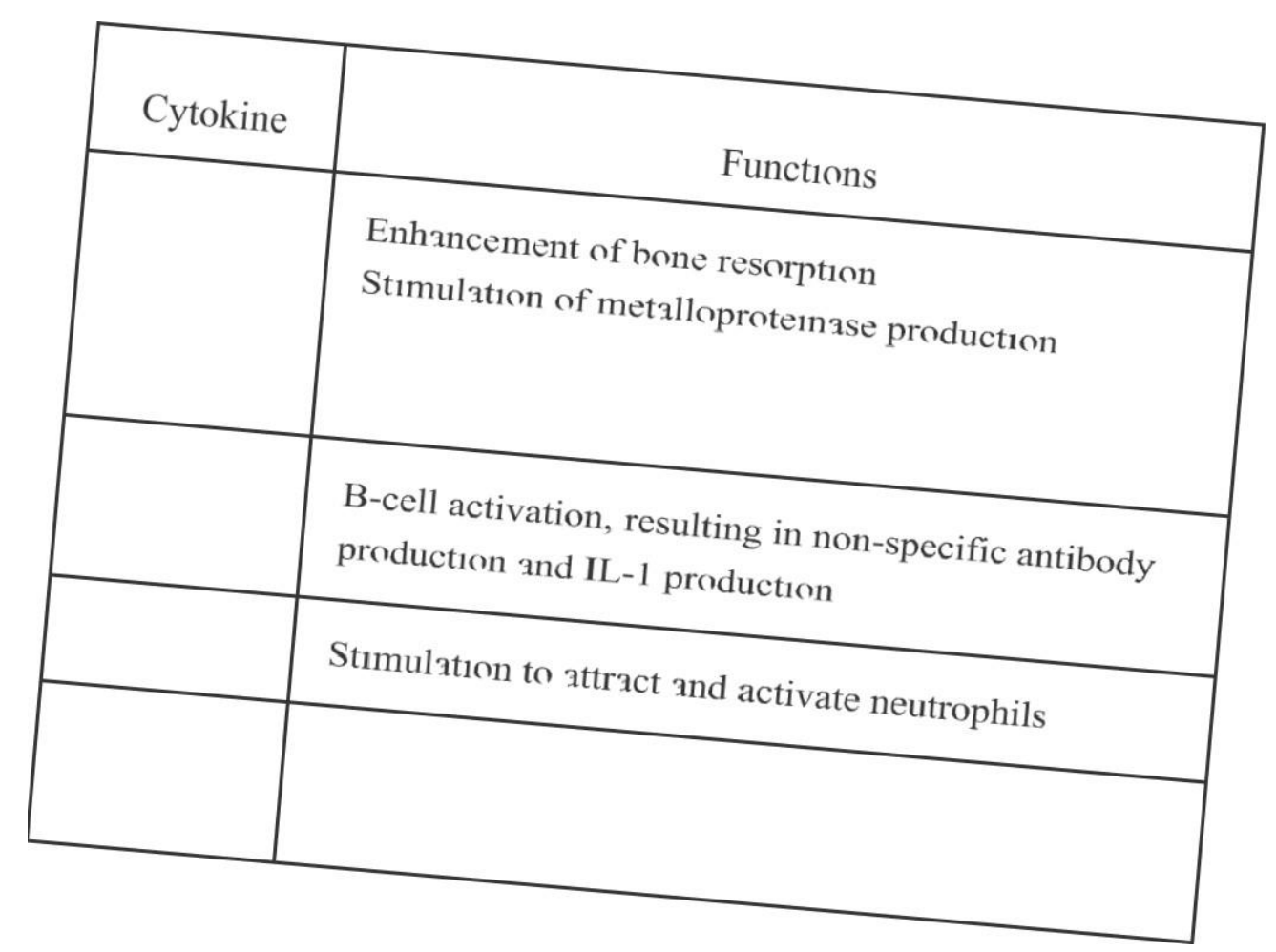

expression. This includes the inflammatory response, innate and adaptive immunity, bacterial colonization and other modifying factors (i.e. stress effect of smoking, etc.). The periodontal diseases, chronic period ontitis and aggressive periodontitis, are not considered as "simple genetic diseases", in which a mutation in a single gene causes some disruption of a specific protein, but as a "complex disease" in which many genes as well as other environmental factors contribute ${ }^{(1)}$, to the onset and severity of the disease. The genetic variants (polymorphisms) that contribute to complex di seases are prevalent in any population and are often reported to differ between diseased and healthy individuals. Because of the inflammatory nature of periodontal destruction, researchers are searching a connection between periodontal diseases and variants in genes that are 
involved in the inflammatory and immune responses. Wide ranges of genes exist and the search is on for variation in genes whose products have been associated with periodontal destruction.

As the immune system plays a crucial role in the pathogenesis of periodontitis, researchers have concentrated on the identification of genetic polymorphisms in several aspects of host immunity. Differences in the expression of cytokines, especially proinflammatory cytokines, are of great interest in periodontal research. [29]

\section{CYTOKINES AND ALVEOLAR BONE LOSS 1301}

The innate and acquired immune responses are both thought to play a role in periodontal bone resorption. When activated,cell types produce cytokines that are potent inducers of bone resorption. PMNs and monocytes of the innate immune response produce IL-I and TNF that can stimulate bone resorption. Studies suggest that overproduction of IL- 1 , TNF-u by the innate host defense is a major contributor to periodontal bon

of the adaptive immune response osteoblasts) produce RANKL, which is a memb es that is one of the most potent inducers of osteoclast formation and activity. Eviden e response plays a significant role in periodontal disease was demonstrated $\mathrm{b}$ alis-induced bone

absence of functional lymphocytes and that greater bone loss occurs when lympho cytes are activated by antigenic stimulation. Thus, both the innate and adaptive arms of the immune response are capable of stimulating events that lead to destruction of periodontal tissues. Moreover, interactions between them are likely to amplify the osteolytic capacity of each. Based upon this concept; a goal of periodontal therapy that may be effective would be dampening the overreaction of the host response so that the inflammation front does not reach concentration and a critical distance to the al veolar bone.

CYTOKINES AND THE LOSS OF GINGIVAL CONNECTIVE TISSUE 1301

Periodontopathic bacteria do not reside periodontal tissue in large numbers but chronic inflammation and a continuous and sometimes excessive host response. It is generally believed that mo st periodontal destruction results from activating host proteases collectively known as matrix metalloproteinases.

An early event in the pathogenesis ofperiodontal disease is dissolution of approximately $70 \%$ of the gingival connective tissue. The presence of proinflammatory cytokines (IL-I) inhibits the intracellular route of collagen breakdown while stimulating the extracellular route by activating MMPs to degrade collagen. TGF- $\beta$ has the opposite effect Activation of proinflammatory cytokines and Other medi ators result in an altered matrix, which, in turn, may affect cell function and subsequent tissue remodeling.

However, recognition that MMPs have multiple functions raises the possibility that blocking MMP activity can have unanticipated consequences. Thus, future therapeutic efforts in periodontics will likely focus on specific MMP inhibitors targeted to welldefined MMP molecules.

\section{CYTOKINES AND APOPTOSIS OF MATRIXPRODUCING CELLS}

The breakdown of gingival connective tissue would not be problematic if there were adequate repair mechanisms. Therefore factors that limit repair may be as important as those that initiate tissue loss. One mechanism by which this may occur is the stimulation of

$$
1(1
$$

apoptosis, programmed cell death, in critical periodontal cells such as fibroblasts or osteoblasts. One of the most striking features of periodontal tissue destruction is the loss of fibroblasts. This may occur through apoptosis of fibroblasts that are present in areas Of the gingiva associated with inflammation.

One study indicated that P.gingivalis infection stimulates TNF production and TNF causes most of the programmed cell death of fibroblasts. Thus, the host response has a more prominent role in apoptosis of fibroblasts than the direct effect Ofb acteri al products.

Regardles s ofthe mechanisms, the loss offibroblasts and osteobalsts is likely to be a significant event and 
may limi $t$ the natural repair process that would be expected to occur. Loss of attachment may occur not just because matrix is destroyed, but also because the potential to repair damage induced by bacterialstimulated cytokine production is limited by apoptosis of matrix-producing cells. ( Table-2, Fig-I)

\section{CYTOKINE THERAPY 1221}

The use of cytokines to change the course of the disease or to alleviate symptoms or side effects of other therapies is becoming important in clinical medicine. Cytokines can theoretic ally be used as therapeutic modalities in two forms. One is over production of cytokines may be inhibited by the cy tokines suppressing anti inflammatory drugs. Alternatively, missing, defective or reduced cytokines and /or their receptors can be replaced directly to reconstitu te a reduced immune system or used to stimulate further the immune system in cases of overwhelming infection neoplasias. These therapies can be achieved using recombinant cytokines or gene encoding for them.

Initially, cytokine therapy was used for hematopoiesis. Recombinant cytokines and or their inhibitors can be used in the control Of rheumatoi t-term clinical trails have $b$ riety ofcytokine-blocking mechanisms.

In different clinical situations, cytoki ines, antibodies to cytokine ines and agonists could a tment. Two major problems $r$ he need to achieve the cytokine levels

or blockade in the long term, and the second is to overcome the adverse outcomes that may result from systemically blocking or increasing cytokines that are normally involved in homeostasis.

\section{IMPLICATION OF ANTI-CYTOKINE THERAPY FOR PERIODONTITIS}

There are 3 basic therapeutic strategies, including neutralization of cytokines, blockage of cytokine receptors, and activation of anti-inflammatory pathways such as immunosuppressive cy tokines.

TNF-u is especially a target molecule for its neutralizing therapeutics. Anti-TNF-(I antibodies can effectively attenuate or prevent inflammation of arthritis in experimental models. TNF- a can also be neutralized with genetically engineered sTNF-RII. Two therapeutics, Infliximab and Etanercept have been available commercially and proven in the treatment of rheumatoid arthritis

Although there are drawbacks to reducing inflammation using anti-cytokine therapeutics, there are several studies that show the potential ofusing IL- 113 and TNF-u antagonist to reduce tissue destruction in periodontal diseases. These researchers applied exogenous SIL- I RI and sTNF-RII to the gingival tissue of non-human primates with experimental periodontitis, inhibition of inflammatory cell infiltration, alveolar bone loss, and loss of tissue attachment. These are quite exc iting results relating to the regulation of the immune reaction in connective tissue, although future studies should assess microbial infection. [34]

\section{CONSIDERATION OF ANTIMICROBIAL THERAPY FOR ANTI-CYTOKINE THERAPY IN PERIODONTAL TREATMENT}

With antimicrobials, caution must be taken to prevent inapparent infection without inflammatory symptoms when anti-cytokine therapy is performed. If anticytokine therapy is applied to periodontal treatment we may use chemical plaque control reagents chlorhexidine gluconate in addition mechanical control. For a future antimicro responses antimicrobial therapeutics. Hostderived antimicrobial peptides have received much attention. Defensins, 
Cytokines in periodontal health and disease

especially, have been detected in periodontal tissue by $\mathrm{i}$ mmunohistochemistry.

One study found oral epithelium to be a major source of these peptides, suggesting that defensins may be secreted into the oral cavity and act as an innate defense on the gingival surface. Thus, their clinical application has been proposed. [35] These peptides kill bacteria by making holes in the bacterial cell wall. Synthetic human B-defensin 2 (hBD-2) has bactericidal activity in saliva but not in serum. It may be possible to add host-derived antimicrobial pepti des into future practice.

\section{FUTURE ANTI-CYTOKINE THERAPY FOR PERIODONTAL TREATMENT BASED ON FIBROBLAST BIOLOGY}

Human gingival fibroblasts (HGF) are involved in immune and inflammatory responses. Furthermore, HGFs are the major cell population in periodontal tissue. If we could modify HGF activities, these cells could serve as therapeutics by secreting anti-cytokine and antimicrobial molecules. Transfer of exogenous genes such as sTNF-RII and hBD-2 genes to HGF would modify the conditions of inflammation and infection in periodontal tissue.

The TNF-RII gene modified not to have a cytoplasmic domain is introduced to gingival fibroblasts to overexpress sTNF-R11. Produced sTNF-R11 binds $\mathrm{TNFu}$ around gingival fibroblasts to block binding ofTNF-a to mTNF-Rs. At the same time, the hBD-2 gene is also introduced to gingival fibroblasts, resulting in overexpression of hBD-2 peptide in the gingival tissue. Produced hBD-2 may be inactive in the tissue because of serum components, but could turn active when it exudes into periodontal pockets or is dissolved in saliva. The transfer of the hBD-2 gene into gingival fibroblasts is complimentary to its native production by gingival epithelium. Active regulation of gingival fibroblast functions may have great potential for periodontal therapy.

PLATELET-RICH PLASMA (PRP): A SOURCE OF

\section{MULTIPLE AUTOLOGOUS GROWTH FACTORS FOR BONE GRAFTS}

The use of platelet-rich plasma (PRP) is one strategy available today that can modulate and enhance wound healing.
Sreedevi et al

The processing of PRP fundamentally involves the sequestration and concentration of platelets and, therefore, the many growth factors they contain. The oversimplified strategy is to amplify and accelerate the effects ofgrowth factors contained in platelets, which are the universal initiators ofalmost all wound heal ing.

By taking advantage of all of the natural regeneration pathways, and using all the known and as yet to be identified growth factors in platelets, autologous platerich plasma, which is nontoxic and nonimmunoreactive, accelerates existing woundhealing pa thways.[36]

PRP also modul ates and upregulates one growth factor's function in the presence ofsecond or third growth factor. It is this specific feature that separates PRP growth factors from recombinant growth factors, which are single growth factors that focus only on a single regeneration pathway.

Specific studies of PRP have identified at least three important growth factors in the alpha granules sequestered platelets: PDGF, TGF- $\$ 1$, and TGF-ß32. In addition, other studies have documented the presence of IGF-I in platelets from peripheral human blood tests. [37]

PRP represents an advance over standard grafting techniques. It offers the surgeon access to growth factors with a simple and available technology.

\section{CONCLUSION AND FUTURE CONSIDERATION}

The conversion of gingivitis to periodontitis is likely to involve the progression of an inflammatory front to deeper areas of connective tissue. The reasons why this occurs have not been established. One mechanism may be that bacteria acquire the ability to penetrate deeper into the connective tissue, or the host defense is perturbed, allowing deeper penetra or, more likely, their product xpression ofpro-inflamm $n$ play an important role in the upregulation of the inflammatory response. This on of secondary mediators yclooxygenase products, w he degree of inflammatio be induced that destroy connective

Journal of Scientific Dentistry, 1(1), 201 
tissue, Simultaneously, cytokines may reduce the capacity to repair the damaged tissue through apoptosis of resident cells such as fibroblasts. And finally, the induction of an inflammatory cascade stimulates osteoclastogenesis that results in destruction ofbone.

Thus, cytokines are a significant and integral part of the host response to periodontal infection. Additionally,

these molecules are important as physiologic mediators in the periodontium, serving in both normal processes and as pathogenic mediators. A therapeutic goal in

clinical periodontics can be aimed at maintaining a physiological role for the cytokines while recognizing

that their overproduction results in pathologic changes Futther studies in this exiciting field are awaited.

\section{REFERENCES}

1. Kenneth T,Miyasaki, Russell J,Nisengard, Susan Kinder Haake. Immunity and inflammation: Basic concepts. In: Newman,Takei \& Carranza (cds): Carranza's Clinical Periodontology.9th edition. W.B.Saunders Company; 2003:118 19 .

2. P.R.Garant(ed). Gingiva:basic science correlations. In: Oral cells and tissues. Quintessence publishing Co, 003.13640.

3. H.Okada, S.Murakami.Cytokine expression in periodontal health and disease. Crit Rev Oral Biol Med 1998; 9(3): 24866

4. Kjeldsen M, Helmstrup P, Ben dtzen K. Marginal Periodontitis and Cytokines: A Review of literature, J Periodontol 1993; 64: 1013-22.

5. McFarlane C, Meikle M. Interleukin-2, interleukin 2 receptor and interleukin 4 levels are elevated in the sera Of patients with periodofital disease. J Periodont Res $1991 ; 26: 402-08$

6. Jandinski JJ, Stashenko P, Feder LS, et al. Localization Of interleukin I B in human periodontal tissue. J Periodontol 1991; 62:36 43 .

7. Hönig J, Rordorf-Adam C, Siegmund C, Wiedemann W, Erard F. Increased interleukin I beta (IL I B ) concentration in gingival tissue fFom periodÖntitis patients. J Pe

affajee A, Socransky SS, Goodson J. Comparison of different data analyses for detecting changes in attachment level. J Clin Periodontol 1983; 10:298-10. Stashenko P, Fujiyoshi P, Obernesser MS, Prostak L,
HafTajee AD, Socransky SS. Levels of interleukin 113 tissue from sites of active periodontal disease. J Clin Periodontol 1991; 18:548-54.

10. Stashenko P, Jandinski J, Fujiyoshi P, Rynar J, Socransky SS. Tissue levels of bone resorptive cytokines in periodontal disease. J Periodontol 1991 62:504 09.

11 Masada MP, Persson R, Kenney JS, Lee S W, Page RC, Allison AC. Measurement of interleukin-lu and-IB in gingival crevicular fluid: Implications for the pathogenesis of periodontal disease. J Periodont Res 1990; 25:156-63.

12. Offenbacher S, Pinnix K, Odle B. The measurement of tumor necrosis factor in inflamed periodon tal tissue. J Dent Res 1988; 67 (Spec. Issue):346(Abstr. 156).

13. Bartold PM, Haynes DR. Interleukin 6 production by human gingival fibroblasts. J Periodönt Res 1991; 26:339 45 .

14. Charon J, Luger TA, Mergenhagen SE, Oppenheim JJ.

Increased thymocyte-activating factor in human gingival fluid during gingival inflammation. Infect Immun 1982; 38:1190 95 .

15. Mergenhagen SE. Thymocyte activating factor(s) in human gingival fluids. J Dent Res 1984; 63:461 64.

16. Luger TA, Stadler BM, Luger BM, et al. Murine

epidermal cell derived thymocyte-activating factor resembles murine interleukin 1. J Immunol 1982;

$128: 214752$.

17. Kabashima H, Maeda K, Iwamoto Y, et al. Partial characterization of an interleukin-I-like factor in human gingival crevicular fluid from patients with chronic inflammatory periodontal disease, Infect Immun 1989; 58:2621 27.

18. Lord pew, Wilmoth LMG, Mizel SB, McCall CE. Expression of interleukin-la and $b$ genes by human blood polymorphonuclear leukocytes. J Clin Invest 1991; 87:1312-21.

19. Auron PE, Warner SIC, Webb AC, et al. Studies on the molecular nature of human interleukin 1 . J Immunol

$1987 ; 13811447-56$

20. Rossomando EF, Kennedy JE, Hadjimichael J. Tumour necrosis factor alpha in gingival crevicular fluid as a possible indicator of periodontal dis iol 1990; 35:431-34.

21. Geivelis M. Interleukin-6 levels in gingival crevicular fluid. J Periodontol 1990; 61: 77374.

22. Gemell E, Marshal RI and Seymour GJ. Cytokines and prostaglandins in immune homeostasis and tissue destruction in periodontal disease. Periodontol 2000 $1997 ; 14: 11243$.
23. Gemell E, Seymour Gel. Immunorcgulatory control of Th2 cytokine profiles in periodontal disease. Periodontal 2000 2004; 35:21 41. 
24. Gregory J. Seymour, John J. Taylor. Shouts and whispers: an introduction to immunoregulation in periodontal disease. Periodontol 2000 2004; 35: 913.

25. Moscatelli D, Presta M, Joseph-Silverstein J, Rifkin DB. Both normal and tumor cells produce basic fibroblast growth factors. J Cell Physiol 1986; 129:273-76.

26. Balkwill FR, Burke F.The cytokine network.

27. Nozaki T, Kusumoto Y, Kitamura M, Murakami S, Okada H. Differential mRNA expression of inflammatory cytokines in inflamed gingival tissue. $\mathrm{J}$ Dent Res 1997; 76:30

28. Shapira L, Wilensky A, Kinane DF. Effect of genetic variability on the inflammatory response to periodontal Immunnol Today 1989; 9:299-04.

How to cite this article:

infection. J Clin Periodontol 2005; 32 (Suppl. 6):

7286.

29. S a-Wador Narcs. The genetic relationship to periodontal disease. Periodontology 2000 2003; 32:36 49.

30. D.T.Gra ves and D.Cohran. The contribution of lilterleukin-1 and tumor necrosis factor to periodontal tissue destruction. J Periodontol 2003; 74:391 01.

31. Graves B, Oskoui M, Volenjnikova S. TNF modulates fibroblast apoptosis, PMN recruitment, and osteoclast formation in response to $\mathrm{P}$. gingivalis infection. $\mathrm{J}$ Dent Res 2001; 80:1875-79.

32. Takashiba S, Naruishi K, Murayama Y. perspective of cytokine regulation for periodontal treatment: fibroblast biology. J Periodontol 2003; 74: 10310.

33, Graves DT, Delima AJ, Assuma R, Amar S, Oates T, Cochran D. Interleukin-I and TNT? antagonists inhibit the progression of inflammatory cell infiltration toward alveolar bone in experimental periodontitis. J Periodontol 1998; 69:1419-25.

Address for correspondence:

Dr. Sreedevi M

Department Of Periodontics

Indira Gandhi Institute of Dental Sciences,

Sri Balaji Vidhyapeeth

Pondy - Cuddalore Main Road,

Pillayarkuppam, Puducherry 607402 Email:

sreedevi206@gmail.cöm

44. DelimaAJ, Oates T, Assuma R. Soluble antagonists to IL I and TNF inhibits loss of tissue attachment in experimental periodontitis, J Clin Periodontol 2001 ; $28233-40$

Sreedevi M, Vineela Katam Reddy, Anitha K. Cytokines in Periodontal Health \& Disease $: 1(15-24$.

Source ofSupport: Nil, Conflict of Interest: None declared 